\title{
Fertilizer Nitrogen Timing and Uptake Efficiency of Hybrid Hazelnuts in the Upper Midwest, USA
}

\author{
Lois C. Braun ${ }^{1}$ and Jeffrey H. Gillman \\ Department of Agronomy, University of Minnesota, 411 Borlaug Hall, \\ Upper Buford Circle, St. Paul, MN 55108
}

\author{
Michael P. Russelle \\ Soil Scientist, USDA-ARS Plant Science Research Unit, St. Paul, MN 55108
}

Additional index words. Corylus, tracers, nitrogen allocation, nutrient recommendations

\begin{abstract}
Hybrids of Corylus avellana, $C$. americana and $C$. cornuta, are being developed as a potential crop for the Upper Midwest of the United States, but little is known about fertilizer nitrogen $(\mathrm{N})$ management. We hypothesized that $\mathrm{N}$ application when the bushes were most fully leafed out would result in highest $\mathrm{N}$ uptake efficiency (NUE). We used ${ }^{15} \mathrm{~N}$-labeled ammonium nitrate to measure NUE from soil applications in mid-April, late April, late May, early August, and mid-September. Nitrogen applied in either mid- or late April never comprised more than $5 \%$ of the total $N$ in shoots or leaves, suggesting that $\mathbf{N}$ used for early leaf expansion came primarily from stored reserves. Applications made after April demonstrated that $\mathbf{N}$ was quickly translocated to rapidly growing plant parts: May applications comprised $9 \%$ of the $\mathrm{N}$ in leaves collected in July; August applications comprised $12 \%$ of the $\mathrm{N}$ in nut kernels collected in September; and September applications comprised $9 \%$ of $\mathrm{N}$ in catkins collected in October. Nitrogen applied in August and September appeared in new shoots the following April at higher levels than it did aboveground the previous October, showing that $\mathbf{N}$ applied late in the season may be stored belowground over the winter. NUE was highest for August and September applications at one site and August and mid-April applications at the other, implying that summer is generally the best time to apply $\mathbf{N}$ for most efficient uptake. However, overall NUE was low, only $5 \%$ for August applications, suggesting a need to develop other methods of improving NUE in hybrid hazelnuts.
\end{abstract}

Hybrid hazelnuts are a potential new alternative to annual row crops in the Upper Midwest of the United States. These are hybrids between Corylus avellana L., the common European hazel, which is the basis for commercial production worldwide, and two species of native American hazels, the common American hazel (Corylus americana Walter) and the beaked hazel (Corylus cornuta Marsh). The two American species may confer genetic resistance to Eastern Filbert Blight (EFB) as well as the cold hardiness needed in the region (Rutter and Shepard, 2002). Woody perennial crops such as hazelnuts may reduce soil erosion, improve soil and water quality, sequester carbon in the soil, and reduce agricultural energy use while enhancing wildlife

\footnotetext{
Received for publication 4 Feb. 2009. Accepted for publication 25 June 2009.

We appreciate funding from North Central Region SARE, The Land Institute's Natural Systems Agriculture Fellowship Program, and from the University of Minnesota's Southeast Regional Partnership and Grant-in-Aid programs. We also thank Phil Rutter of Badgersett Research Corporation and Roy and Teresa Cerling for use of their hazelnut plantings and for their help in the field.

${ }^{1}$ To whom reprint requests should be addressed; e-mail brau0259@umn.edu.
}

habitat and ecosystem diversity (Josiah, 2001; Thevathasan and Gordon, 2004).

A viable hazelnut industry in the Upper Midwest would provide an alternative energy and food crop to help farmers diversify economically while enhancing ecological sustainability. However, the ecological benefits of growing hazelnuts could be undermined if inappropriate nitrogen $(\mathrm{N})$ fertilization practices are used, leading to $\mathrm{N}$ pollution. According to Weinbaum et al. (1992), orchard crops have among the lowest $\mathrm{N}$ uptake efficiency (NUE) of any agricultural crop. The objective of our research program, which is the first replicated research on the agronomics of hybrid hazelnuts in this region, is to improve the viability of hazelnuts as a new crop for the Upper Midwest by developing $\mathrm{N}$ fertilization recommendations that balance crop requirements with environmental goals; optimizing $\mathrm{N}$ application timing is part of this. Research on optimal $\mathrm{N}$ application rates and optimal leaf $\mathrm{N}$ concentrations is reported elsewhere (Braun, 2008).

In Minnesota, the typical recommendation is to apply $\mathrm{N}$ to woody crops in spring (Rosen and Eliason, 2005), but this is problematic because it is a busy time for many growers and because the soil frequently is too wet for tractor traffic. Moreover, applying $\mathrm{N}$ when soils are cold and roots are inactive may contribute to low NUE (Dong et al., 2001). Baron and Stebbins (1981) warned that $\mathrm{N}$ applications in later summer and early fall (August to September) may stimulate late-season shoot growth and delay stem hardening, leading to winter damage. Although Pellett and Carter (1981) showed that this occurs only if plant $\mathrm{N}$ concentrations are very high, as indicated by leaf $\mathrm{N}$ above optimal concentrations, some growers wait to fertilize until after the possibility of growth stimulation has passed in late fall, even as late as early November (personal observation). However, this may not be necessary for these hybrids, which have higher cold hardiness than European hazelnut and delaying $\mathrm{N}$ application may not provide adequate time for $\mathrm{N}$ absorption before cold and wet soil conditions become conducive to $\mathrm{N}$ leaching or runoff (Kowalenko, 1996). Whereas Grasmanis and Nicholas (1971) found that in apples (Malus domestica), $\mathrm{N}$ uptake can occur in the dormant period, Aguirre et al. (2001) found that little $\mathrm{N}$ uptake occurs when $\mathrm{N}$ is applied after leaf senescence.

The most efficient time for $\mathrm{N}$ uptake by woody crops appears to be when plants are fully leafed out and actively growing. Titus and Kang (1982) reported that apple trees take up $\mathrm{N}$ continuously throughout the growing season with a peak in summer. In peaches (Prunus persica), Munoz et al. (1993) found very little $\mathrm{N}$ uptake during dormancy through budbreak, maximum uptake during rapid shoot growth and fruit expansion, and reduced uptake after August, when translocation to storage was high. Weinbaum et al. (1978) showed a clear correlation between NUE of prune trees (Prunus domestica) and the presence of leaves, which they attributed partly to the fact that $\mathrm{N}$ uptake from the soil and $\mathrm{N}$ assimilation in the plant require photosynthetic energy from leaves and partly to the fact that leaves generate a transpirational demand for water, enhancing nutrient movement to the roots. Millard (1996) reported that from $18 \%$ to $93 \%$ of $\mathrm{N}$ used during budbreak and leaf expansion in apples was derived from stored reserves in bark and roots depending on the age of the plant and prior $\mathrm{N}$ status. Nitrogen uptake from the soil increases in walnut (Juglans regia) as plant reserves are depleted and remains high through the rest of the growing season up until leaf senescence (Weinbaum and Van Kessel, 1998).

These findings are consistent with ${ }^{15} \mathrm{~N}$ research on European hazelnuts in Oregon (Olsen, 1997; Olsen et al., 2001). They found that spring-applied $\mathrm{N}$ was incompletely used in the season of application: more fertilizer $\mathrm{N}$ appeared in the leaves that emerged two seasons after application than in leaves that emerged the season of application with some remaining in the roots at the end of the second season. The implication is that initial spring growth in hazelnuts is fueled by stored $\mathrm{N}$ reserves. These researchers concluded that although the $\mathrm{N}$ applied in the spring contributes to growth in the current season, its main value may be for building reserves for longterm crop health and longevity. In his nutrient management guide for European hazelnuts in Oregon, Olsen noted that the most efficient uptake of soil-applied $\mathrm{N}$ occurs during active 
spring growth, which is from May to June in that environment (Olsen, 2001).

The objective of this study was to determine the effect of $\mathrm{N}$ application time on fertilizer NUE in hybrid hazelnuts in Minnesota using ${ }^{15} \mathrm{~N}$-enriched fertilizer applied on five dates: mid-April, late April, late May, early August, and mid-September.

\section{Materials and Methods}

\section{Experimental Sites and \\ Experimental Design}

In 2005 , we conducted ${ }^{15} \mathrm{~N}$ tracer studies at two sites in southeast Minnesota. One site was on a private research facility near Amherst (Fayette silt loam soil, pH 5.6, organic matter $2.1 \%$, lat. $43^{\circ} 64^{\prime} \mathrm{N}$, long. $91^{\circ} 94^{\prime} \mathrm{W}$ ) and the other was on a farm near Fillmore (Renova silt loam soil, $\mathrm{pH} 6.4$, organic matter $2.4 \%$, lat. $43^{\circ} 76^{\prime} \mathrm{N}$, long. $92^{\circ} 22^{\prime} \mathrm{W}$ ). Bushes at both sites were seed-propagated. Half of the bushes at Amherst were 13 years old and half were 9 years old in 2005; all bushes at Fillmore were 8 years old. Bushes at both sites were planted $\approx 1.5 \mathrm{~m}$ apart in hedge rows, which were spaced $\approx 4 \mathrm{~m}$ apart, for a plant population of 1667 ha. There was no weed control within rows, but the alleyways were mowed. Consequently, competition from weeds, mostly coolseason grasses, was high. The experimental design was a randomized complete block with four blocks arranged by landscape position and by age and half-sib genetic line of bushes. Each block contained five treatment bushes and one control bush, which we selected for evenness of size. At least one untreated bush was present between each experimental bush. We measured initial height and width of each bush.

\section{Application Dates}

Our experimental treatments were five fertilizer application dates: 11 Apr., 26 Apr., 26 May, 1 Aug., or 10 Sept. 2005. Fertilizer was applied once to each plant, except for the controls, which received none. We hypothesized that NUE would be highest for the late May and August applications, when bushes are completely leafed out but before they begin to senesce. The mid-April date corresponds about to the earliest time growers might be able to fertilize after the soil thaws but before budbreak; the late April date corresponds to early shoot expansion. The mid-September date was chosen to test the idea that it may be about the time when $\mathrm{N}$ uptake and translocation stops in the fall.

\section{Preparation and Application of Tracer Solution}

We estimated how much ${ }^{15} \mathrm{~N}$-enriched material we would need to apply to harvest plant tissues with greater than 0.4 atom $\%{ }^{15} \mathrm{~N}$ based on estimates of total $\mathrm{N}$ quantity in 13year-old hazelnut bushes and assuming 5\% uptake efficiency. We used 60 atom percent $(\mathrm{A} \%){ }^{15} \mathrm{~N}$-enriched material, half as $\mathrm{KNO}_{3}$ and half as $\left(\mathrm{NH}_{4}\right)_{2} \mathrm{SO}_{4}$, mixed with fertilizergrade natural abundance $\mathrm{NH}_{4} \mathrm{NO}_{3}$ to obtain a final ${ }^{15} \mathrm{~N} \mathrm{~A} \%$ of 4.079 . We prepared the fertilizer solution for the entire experiment at one time. At each application date, we applied a total of $6.15 \mathrm{~g} \mathrm{~N}$ in $2 \mathrm{~L}$ water to one bush in each block. This supplied just over half the $\mathrm{N}$ of the rate, $11 \mathrm{~g} / \mathrm{plant}$, that we found to be best for hybrid hazelnuts in their sixth to eighth seasons in N-rate trials at the Fillmore site (Braun, 2008). We poured the solution in a ring around each plant $\approx 20$ to $30 \mathrm{~cm}$ from the center of the crown. After the fertilizer solution had infiltrated, we applied an additional $8 \mathrm{~L}$ of tap water to promote movement of $\mathrm{N}$ into the soil. At each application, we saved a sample of tracer solution for analysis of $\mathrm{N}$ concentration and $\mathrm{A} \%$.

\section{Sampling}

Year of tracer application (2005). Each time tracer was applied, except for the first date, we also sampled leaves and bark from all bushes to which tracer had previously been applied as well as from the control bushes. We also sampled in early July and just before leaf drop in early October for a total of six sampling dates in 2005: 26 Apr., 26 May, 4 July, 1 Aug., 10 Sept., and 5 (at Fillmore) or 12 (at Amherst) Oct.

We collected $\approx 15$ leaves per bush, selecting the youngest fully expanded leaf on shoots fully exposed to the sun. An exception was 26 Apr., when we collected entire newly emerging shoots because individual leaves were quite small. We used a vegetable peeler to remove strips of bark from five or six stems per plant $\approx 10$ to $30 \mathrm{~cm}$ from the base. These strips were 3 to $5 \mathrm{~cm}$ long and included epidermis, cortex, and vascular layers but only minimal woody tissue from the interior of the stem. We collected bark from a variety of stem sizes and ages. At Fillmore, we also sampled immature nuts in early August and mature nuts in September. Commercial harvest of nuts prevented collection of nut samples at Amherst. In October, we sampled new catkins at both sites.

We dried all samples at $60{ }^{\circ} \mathrm{C}$, grouped by treatment and sampling date, and ground them to pass a $0.5-\mathrm{mm}$ screen. To reduce crosscontamination, we cleaned the grinder with a vacuum between samples and cleaned it further with ethanol between treatments. We shelled the nuts to extract the kernels, which we ground with a mortar and pestle. Samples were analyzed for ${ }^{15} \mathrm{~N}$ at the UC Davis Stable Isotope Facility on a PDZ Europa ANCA-GSL elemental analyzer interfaced to a PDZ Europa 20-20 isotope ratio mass spectrometer (Sercon Ltd., Cheshire, UK).

On all application dates, we also collected soil samples, to a depth of $45 \mathrm{~cm}$, to determine soil moisture gravimetrically.

Year after tracer application (2006). At Amherst, we coppiced all bushes at ground level on 24 Apr. 2006 to determine aboveground biomass at budbreak after first measuring height and width. We chipped the entire bushes with a garden shredder and then dried the chips at $60{ }^{\circ} \mathrm{C}$. We weighed aboveground dry mass ground subsamples to pass a $0.9-\mathrm{mm}$ screen and subsampled again before grinding to pass a $0.5-\mathrm{mm}$ screen as described previously. On 31 May, we harvested stump sprouts that were emerging where we had coppiced bushes and analyzed them as described previously.

On 22 Apr. 2006, we sampled twigs at Fillmore, which we separated into woody twig material and newly emerging shoot material, which was analyzed separately. The new shoot material was at a similar stage of development as the new shoot material collected a year earlier on 26 Apr. Then, on 22 Nov. 2006, 1 year after the final tracer application, we harvested whole bushes for aboveground biomass and ${ }^{15} \mathrm{~N}$ content after first measuring their height and width as we had done at Amherst that spring. At that time, we also collected nuts and fall leaves.

\section{Data Analysis}

We calculated the fraction of $\mathrm{N}$ derived from fertilizer (fNdff):

$$
\begin{aligned}
\mathrm{fNdff}= & \left(\mathrm{A} \%_{\text {sample }}-\mathrm{A} \%_{\text {control }}\right) / \\
& \left(\mathrm{A} \%_{\text {fertilizer }}-\mathrm{A} \%_{\text {natural abundance }}\right)
\end{aligned}
$$

where:

$\mathrm{A} \% \%_{\text {sample }}$ was the atom $\%{ }^{15} \mathrm{~N}$ for the sample from a fertilized plant;

$\mathrm{A} \%{ }_{\text {control }}$ was the atom $\%{ }^{15} \mathrm{~N}$ for the same tissue type collected from a control plant in the same replicate on the same sampling date;

$\mathrm{A} \% \%_{\text {fertilizer }}$ was the atom $\%{ }^{15} \mathrm{~N}$ for the tracer solution (4.078 A\% N, SE $=0.007)$; and

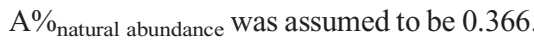

We calculated the aboveground NUE:

$$
\begin{aligned}
\mathrm{NUE}= & (\mathrm{fNdff} \times \mathrm{N} \text { concentration } \\
& \times \text { aboveground dry biomass } \\
& \times 100 / \text { applied } \mathrm{N}
\end{aligned}
$$

We calculated bush growth as the difference between bush volume before and after the experiment assuming a cylindrical shape where volume $=$ height $\cdot \pi(\text { width } / 2)^{2}$. We also analyzed growth by regression on aboveground dry mass with initial bush volume as a predictor.

Statistical analysis was by analysis of variance (ANOVA) using Student Statistix analytical software (Version 7.1; Tallahassee, FL) to compare treatment effects within a tissue type and sampling date. Means separation was determined with Fisher's least significant difference at $P=0.05$. We verified the ANOVA with regression analysis using ARC software (XLISP-PLUS Version 3.04; Cook and Weisberg, St. Paul, MN). Using bush biomass as a covariate improved statistical significance as did including a categorical binomial variable for infection with big bud mites (Phytoptus avellanae Nal. and Cecidophyopsis vermifomis Nal.), which was negatively correlated with growth. At Amherst, one plant was excluded from the analysis because it was infected with EFBt (Anisogramma anomola) and appeared to be dying. 


\section{Results and Discussion}

Weather. Rainfall was close to normal for both sites in 2005 with nearly $75 \mathrm{~cm}$ from 1 Apr. through 30 Sept., well distributed through the growing season. The amount of rain that fell within $5 \mathrm{~d}$ after each fertilization date did not differ between the two sites, but Fillmore received $2.2 \mathrm{~cm}$ of rain that Amherst did not receive within $2 \mathrm{~d}$ of the early April application. Soil moisture was slightly higher at Amherst than at Fillmore; at Amherst, it was $25 \%$ in April and declined through the season to a low of $21 \%$ in early September, whereas at Fillmore, it was $19 \%$ in April, declined to $17 \%$ in August, and rose again to $20 \%$ in early September.

Dates of last and first frosts were the same at both sites: the last killing frost in the spring $\left(-2{ }^{\circ} \mathrm{C}\right)$ occurred on 4 May, the last mild frost $\left(0{ }^{\circ} \mathrm{C}\right)$ on 16 May. The first frost in the fall was $-2{ }^{\circ} \mathrm{C}$ and occurred on 8 Oct. Budbreak occurred in mid-April at both sites, but there were no fully expanded leaves until early May. Leaf senescence was not significant until mid-September; leaf drop occurred in early October. In the winter after $\mathrm{N}$ applications, colder than normal minimum air temperatures occurred in December and February with warmer than normal minima in January.

\section{Samples Collected the Year of Nitrogen Application (2005)}

Shoots and leaves. As expected, newly emerged shoots sampled in late April contained more than $50 \mathrm{~g} \mathrm{~N} / \mathrm{kg}$, but $\mathrm{N}$ concentration declined in leaves as tissues matured. Leaf $\mathrm{N}$ concentrations stabilized $\approx 21 \mathrm{~g} \mathrm{~N} / \mathrm{kg}$ in early July and maintained that level through early September in both fertilized and unfertilized plants.

Very little fertilizer $\mathrm{N}$ appeared in leaves until late May (Fig. 1), suggesting that $\mathrm{N}$ uptake and assimilation from April applications is low. The highest fNdff observed in leaves in the first year occurred in the late May application sampled $38 \mathrm{~d}$ after fertilization (DAF) in early July and comprised only $9 \%$ of leaf $\mathrm{N}$ at Fillmore and only $5 \%$ at Amherst. Therefore, even this late in leafout, $91 \%$ to $95 \%$ of leaf $\mathrm{N}$ in leaves was derived either from endogenous $\mathrm{N}$ reserves or from mineralized soil N. In general, fertilizer applied in late April, late May, and early August appeared at the highest levels in leaves collected on the first sampling date after application and at lower levels with subsequent samplings, suggesting that fertilizer was taken up relatively quickly after application but was subsequently diluted by uptake of mineralized soil N.

Bark. Woody bark contained $10 \mathrm{~g} \mathrm{~N} / \mathrm{kg}$ on all sampling dates and was not altered by $\mathrm{N}$ fertilization. As expected, fertilizer $\mathrm{N}$ allocation to bark was very low in the spring but increased through the season, reaching its highest levels in October (Fig. 2). Not only did fertilizer $\mathrm{N}$ applied in the early spring appear in bark at increasingly higher levels as the season progressed, but proportionately more was allocated to the bark the later the $\mathrm{N}$ was applied in the season. The highest fNdff observed in bark in the year of application was $6 \%$ at Fillmore, measured in early October, $26 \mathrm{~d}$ after the September application. This is consistent with Weinbaum et al. (1978) and Olsen et al. (2001), who found that fall-applied $\mathrm{N}$ is stored in the bark or roots for use the next season.

Leaf and bark fraction of nitrogen derived from fertilizer at first sampling after application. Comparing the fNdff for the first sampling date after each application (the 26 Apr. sampling date for the 11 Apr. application date, the 26 May sampling for the 26 Apr. application, and so on) reflects what happens to the fertilizer after application. By this approach (Table 1), leaf fNdff was higher after late May and early August applications than after early April and early September applications at both sites. This is consistent with expectations that $\mathrm{N}$ uptake would be highest in the early summer, when healthy young and fully expanded leaves supply abundant photosynthate for uptake and when warm soils favor root activity. However, differences in leaf fNdff between application dates were significant only at $P<0.10$ by this method of comparing them. By contrast, fertilizer $\mathrm{N}$ contribution to bark increased with later application dates. This increase was nearly linear at Fillmore, whereas the pattern was less clear at Amherst.

Nuts. Immature nut kernels sampled in early August at Fillmore contained $\approx 50 \mathrm{~g} \mathrm{~N} /$ $\mathrm{kg}$, whereas mature kernels sampled a month later contained $30 \mathrm{~g} \mathrm{~N} / \mathrm{kg}$, suggesting dilution by carbohydrates as nuts matured. Nitrogen fertilization did not affect $\mathrm{N}$ concentration in nut kernels.

Nitrogen applied on 26 May comprised $6 \%$ of the $\mathrm{N}$ in immature nuts sampled in August, 69 DAF (Table 1), but declined to $3 \%$ of the $\mathrm{N}$ in mature nuts sampled in September, 106 DAF. In contrast, $\mathrm{N}$ applied in early August comprised $12 \%$ of the $\mathrm{N}$ in mature nuts in September at 37 DAF, suggesting that there is strong demand for newly available $\mathrm{N}$ by maturing nuts between August and September. Nut fNdff was negatively correlated with DAF at $P<0.0004\left(R^{2}=\right.$ 0.42 ). This pattern of high levels of fertilizer $\mathrm{N}$ appearing in tissues sampled at the first sampling after an application date, with subsequent decline, is similar to the pattern for leaf fNdff and supports the concept of allocation to plant tissues with high demand for $\mathrm{N}$ at the time of application. It also suggests that fertilizer $\mathrm{N}$ was available for only a short time after application before it was lost by leaching or denitrification or was immobilized by organic matter fixation or weed uptake.

Catkins. Nitrogen concentration in catkins sampled in early October was $\approx 25 \mathrm{~g} \mathrm{~N} / \mathrm{kg}$ and was unaffected by $\mathrm{N}$ application. Highest fNdff in catkins occurred with the August N application date at both sites and was significantly higher for the September application date as well at Fillmore (Table 1). Again, this is consistent with a strong demand for $\mathrm{N}$ in developing catkins in the late summer and fall.

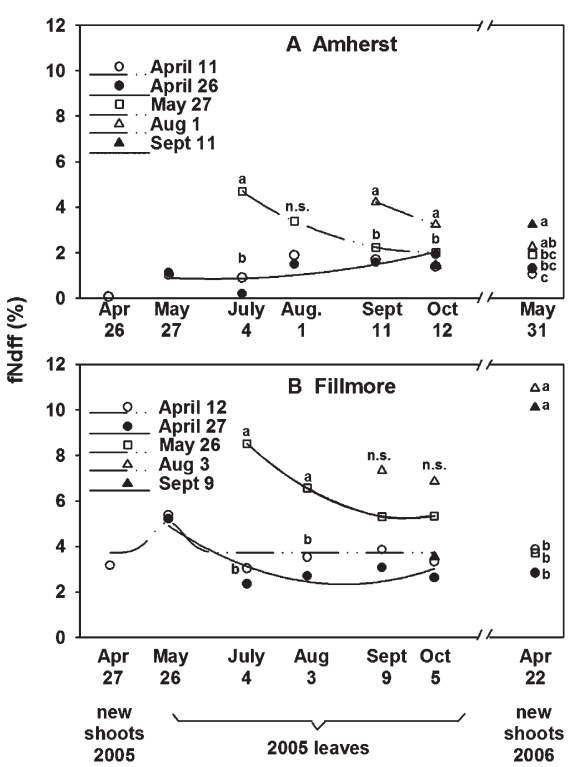

Fig. 1. Mean fraction of nitrogen $(\mathrm{N})$ derived from fertilizer (fNdff) in (A) Amherst and (B) Fillmore young leafy shoots and leaves in 2005 and new shoots in 2006 in response to N applications on five dates in 2005. New shoots at Amherst in 2006 were stump sprouts from where whole bushes had been harvested 1 month earlier. Means were adjusted for aboveground biomass at both sites and for health index at Amherst. Letters signify treatment responses that are significantly different from each other for a given sampling date at $P \leq$ 0.05 . n.s. $=$ nonsignificant at $P \leq 0.05$.

Bark and Twig fNdff

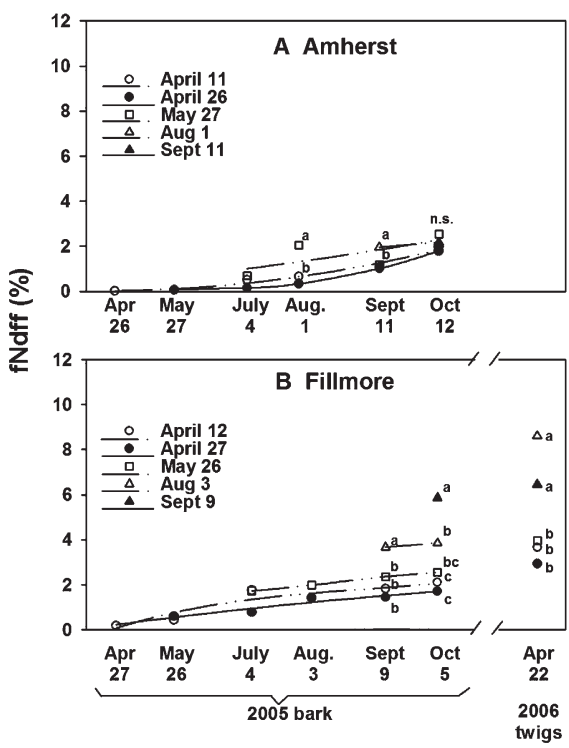

Fig. 2. Mean fraction of nitrogen $(\mathrm{N})$ derived from fertilizer (fNdff) in (A) Amherst and (B) Fillmore bark in 2005 and Fillmore spring twigs in 2006. Means were adjusted for aboveground biomass at both sites and for health index at Amherst. Letters signify treatment responses that are significantly different from each other for a given sampling date at $P \leq$ 0.05 . n.s. $=$ nonsignificant at $P \leq 0.05$. 
Table 1. Mean fraction of nitrogen derived from fertilizer (fNdff) and nitrogen uptake efficiency (NUE) in hybrid hazelnut tissues at Amherst and Fillmore in response to $\mathrm{N}$ application time in 2005 with samples presented in rough chronological order of sampling.

\begin{tabular}{|c|c|c|c|c|c|c|c|c|}
\hline \multirow[b]{3}{*}{ Year } & \multirow[b]{3}{*}{ Tissue } & \multirow[b]{3}{*}{ Site (month of sampling) } & \multicolumn{5}{|c|}{$\mathrm{N}$ application date (in 2005) } & \multirow{3}{*}{$\begin{array}{c}P \text { value for analysis } \\
\text { of variance }\end{array}$} \\
\hline & & & 11 Apr. & 26 Apr. & 26 May & 1 Aug. & $10 \mathrm{Sept}$. & \\
\hline & & & \multicolumn{5}{|c|}{ 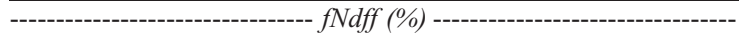 } & \\
\hline \multirow[t]{8}{*}{2005} & Leaves $^{\mathrm{z}}$ & Amherst & $1.0 \mathrm{~b}$ & $0.9 \mathrm{~b}$ & $5.4 \mathrm{a}$ & $4.8 \mathrm{a}$ & $1.3 \mathrm{~b}$ & 0.0863 \\
\hline & & Fillmore & $2.9 \mathrm{~b}$ & $5.0 \mathrm{ab}$ & $8.5 \mathrm{a}$ & $7.2 \mathrm{a}$ & $3.2 \mathrm{~b}$ & 0.0839 \\
\hline & Bark $^{z}$ & Amherst & $0.6 \mathrm{~b}$ & $0.1 \mathrm{c}$ & $0.8 \mathrm{abc}$ & $1.7 \mathrm{a}$ & $1.4 \mathrm{ab}$ & 0.0449 \\
\hline & & Fillmore & $0.2 \mathrm{~d}$ & $0.6 \mathrm{~cd}$ & $1.6 \mathrm{c}$ & $3.8 \mathrm{~b}$ & $6.0 \mathrm{a}$ & $<0.0001$ \\
\hline & Nuts (immature) & Fillmore (August) & 4.0 & 2.5 & 6.1 & & & 0.1256 \\
\hline & Nuts (mature) & Fillmore (September) & $4.0 \mathrm{~b}$ & $3.4 \mathrm{~b}$ & $3.4 \mathrm{~b}$ & $12.1 \mathrm{a}$ & & 0.0138 \\
\hline & Catkins & Amherst & 2.0 & 1.8 & 3.7 & 4.3 & 1.7 & 0.2188 \\
\hline & & Fillmore & $3.3 \mathrm{c}$ & $2.7 \mathrm{c}$ & $3.7 \mathrm{c}$ & $10.4 \mathrm{a}$ & $8.5 \mathrm{~b}$ & 0.0001 \\
\hline \multirow[t]{8}{*}{2006} & Woody biomass ${ }^{y}$ & Amherst (April) & 1.3 & 1.4 & 1.5 & 2.5 & 2.0 & 0.5410 \\
\hline & & Fillmore (November) & $1.9 \mathrm{~b}$ & $1.8 \mathrm{~b}$ & $2.0 \mathrm{~b}$ & $4.2 \mathrm{a}$ & $5.1 \mathrm{a}$ & $<0.0001$ \\
\hline & Stump sprouts ${ }^{\mathrm{x}}$ & Amherst (May) & $1.1 \mathrm{c}$ & $1.3 \mathrm{bc}$ & $1.9 \mathrm{bc}$ & $2.3 \mathrm{ab}$ & $3.2 \mathrm{a}$ & 0.0090 \\
\hline & Spring shoots ${ }^{\mathrm{w}}$ & Fillmore (April) & $3.9 \mathrm{~b}$ & $2.8 \mathrm{~b}$ & $3.7 \mathrm{~b}$ & $10.9 \mathrm{a}$ & $10.1 \mathrm{a}$ & 0.0007 \\
\hline & Spring twigs ${ }^{\mathrm{w}}$ & Fillmore (April) & $3.7 \mathrm{~b}$ & $2.9 \mathrm{~b}$ & $4.0 \mathrm{~b}$ & $8.6 \mathrm{a}$ & $6.5 \mathrm{a}$ & 0.0201 \\
\hline & Nuts (mature) & Fillmore (November) & $1.8 \mathrm{c}$ & $1.8 \mathrm{c}$ & $1.7 \mathrm{c}$ & $4.8 \mathrm{~b}$ & $11.4 \mathrm{a}$ & $<0.0001$ \\
\hline & Woody biomass ${ }^{\mathrm{y}}$ & Amherst (April) & $4.2 \% \mathrm{a}$ & $1.9 \% \mathrm{~b}$ & $2.2 \% \mathrm{~b}$ & $4.8 \%$ a & $2.5 \% \mathrm{~b}$ & 0.0009 \\
\hline & & Fillmore (November) & $2.8 \% \mathrm{~b}$ & $1.6 \% \mathrm{c}$ & $2.0 \% \mathrm{c}$ & $5.6 \% \mathrm{a}$ & $5.0 \%$ a & $<0.0001$ \\
\hline
\end{tabular}

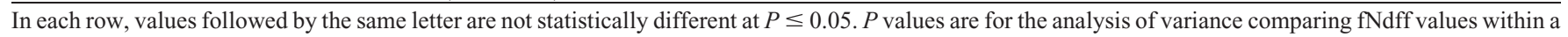
row.

${ }^{z}$ Data for leaves and bark in 2005 relate to the first sampling date after N application as follows: the 26 Apr. sampling date for the 11 Apr. application date, the 26 May sampling for the 26 Apr. application date, and so on. This is equivalent to comparing at the left-most points on the lines for each application date in Figures 1 and 2. These numbers do not correspond perfectly with the means presented in Figures 1 and 2, because the means in the figures were adjusted for aboveground biomass at both sites and for health index at Amherst.

yWoody aboveground biomass was harvested before leafout in Apr. 2006 at Amherst and after leaf drop in Nov. 2006 at Fillmore.

x Stump sprouts were new shoots that grew after whole bushes were harvested at Amherst.

wSpring shoots and the twigs that bore them were harvested at Fillmore at budbreak in Apr. 2006, before whole bushes were harvested.

\section{Samples Collected the Year after Nitrogen Application (2006)}

Stump sprouts and early spring shoots. The only leafy material available to sample at Amherst was from sprouts emerging from the stumps in May, because we had coppiced all aboveground biomass before spring leafout in 2006. The later $\mathrm{N}$ was applied in 2005, the more that appeared in these stump sprouts $(P<0.01$; Fig. 1A; Table 1). The highest proportions of fertilizer $\mathrm{N}$ in the stump sprouts occurred with the September application, for which fNdff was higher than in leaves the previous fall. We speculate that this fertilizer $\mathrm{N}$ in regrowth had been translocated from storage in roots. Alternatively, fertilizer $\mathrm{N}$ remaining in the soil over the winter may have been absorbed in the spring, but we consider this unlikely as a result of potential leaching, denitrification, and microbial immobilization between September and May.

At Fillmore, fNdff in new spring shoots from uncoppiced plants showed patterns similar to the stump sprouts from coppiced plants at Amherst. Whereas spring shoot fNdff from the April and May application dates at Fillmore were similar to leaves sampled the previous fall, spring shoot fNdff from the August and September application dates jumped to $10 \%$ of leaf $\mathrm{N}$, much higher than observed at any time in the year of application (Fig. 1B; Table 1). In woody twigs collected in the spring (Fig. 2B; Table 1), fNdff also was highest from the August and September applications. It was higher than it had been in bark the previous fall for any treatment, but it rose much more for the August application, to nearly $9 \%$ of $\mathrm{N}$ in twigs. This $\mathrm{N}$ was likely in transit to expand- ing shoots from storage tissues. For reasons mentioned previously, we consider it less likely that $\mathrm{N}$ was newly absorbed from the soil.

From results at both sites, we hypothesize that fertilizer $\mathrm{N}$ applied in late summer and early fall was stored in roots over the winter or perhaps in bark near ground level and was mobilized to aboveground parts the next spring. The lower overall levels of fNdff in Amherst stump sprouts, compared with Fillmore spring shoots, suggests dilution of fertilizer $\mathrm{N}$ in the larger bushes at Amherst.

Whole bushes. Growth of bushes that received $\mathrm{N}$ did not differ from growth of the control bushes at either site regardless of $\mathrm{N}$ application date (data not presented). No winter damage was apparent that could be attributed to August or September applications. This is consistent with results from another study (unpublished), in which we observed no increase in winter twig death with early September N applications. Nitrogen application date also did not affect whole bush $\mathrm{N}$ concentration. August and September N applications resulted in the highest fNdff in the aboveground woody biomass at Fillmore (Table 1), but at Amherst, there were no significant application date effects on $\mathrm{fNdff}$ in the aboveground woody biomass.

Nuts. As observed in woody biomass, August and September N applications resulted in the highest proportions of fertilizer $\mathrm{N}$ in nuts collected at Fillmore the second year after $\mathrm{N}$ application (Table 1).

\section{Nitrogen Uptake Efficiency}

NUE and bush size were highly correlated at both sites $(P<0.001)$ (Fig. 3; Tables 2 and $3)$. This was expected because larger plants have larger root systems with which to intercept fertilizer, as found by Ran et al. (1994) in peach trees. Also, larger plants constitute a larger sink for $\mathrm{N}$ and have larger photosynthetic capacity to supply energy for $\mathrm{N}$ uptake and assimilation.

Application date effects on NUE (Table 1) also were significant, but not consistently between sites. Early August was one of the most efficient dates at both sites, but early April was equally efficient at Amherst, whereas September was equally efficient at Fillmore. Early April was the third most efficient time at Fillmore. The lower efficiency of the early April application at Fillmore relative to Amherst may have been the result of the $2.2 \mathrm{~cm}$ of rain that fell at Fillmore but not at Amherst during the $2 \mathrm{~d}$ immediately after that application. This rain may have leached the $\mathrm{N}$ out of the root zone. Considering the two sites together, NUE was significantly higher for August, September, and early April than for late April or late May (Fig. 3).

An explanation for the relatively high $\mathrm{N}$ uptake in August could be the increased demand for $\mathrm{N}$ from nut filling, which occurs mainly in August in hybrid hazelnuts. This kind of "demand-driven uptake" has been noted in pistachios (Pistacia vera L.; Rosecrance et al., 1996) and almonds (Prunus dulcis Mill; Youssefi et al., 2000).

Late April and May were the least efficient $\mathrm{N}$ application times at both sites. This was contrary to our hypothesis that late May applications would be optimal. We had reasoned that photosynthesis in May would supply sufficient photosynthate to the roots for $\mathrm{N}$ uptake and that soil conditions in May should be optimal for rapid $\mathrm{N}$ uptake. A likely explanation for the reduced NUE in 


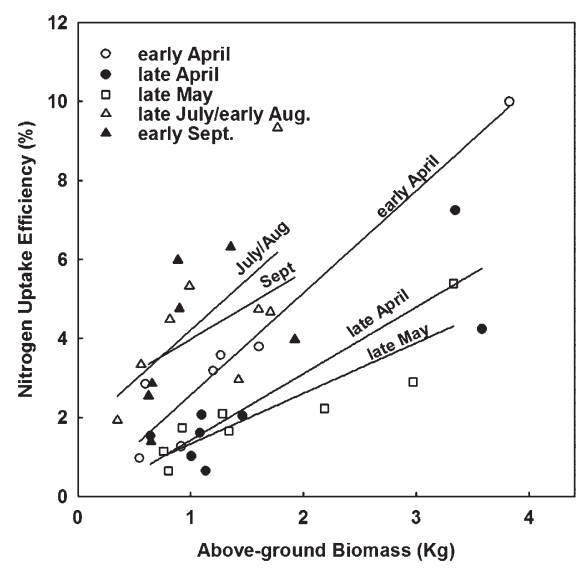

Fig. 3. Nitrogen uptake efficiency (NUE) correlated with aboveground biomass in response to nitrogen $(\mathrm{N})$ applied on five different dates in 2005. Data from Amherst Apr. 2006 and Fillmore Nov. 2006 were combined. NUE was based on $\mathrm{N}$ recovered in aboveground biomass, but did not account for $\mathrm{N}$ removal in nuts and leaf fall or for $\mathrm{N}$ stored in belowground plant parts.

late April and late May could be competition from the cool-season weeds, which are most active at that time. We did not account for $\mathrm{N}$ uptake by competing weeds.

In another experiment, we measured biomass and $\mathrm{N}$ concentration of grasses growing at the base of the hazelnuts and determined that $\mathrm{N}$ uptake by the grass was linearly related to applied $\mathrm{N}$, but in this experiment, we did not sample the grasses for ${ }^{15} \mathrm{~N}$ until after they had begun to senesce (Braun, unpublished data). Thus, although we verified that the grasses were absorbing fertilizer $\mathrm{N}$, we could may have contributed to a reduction in NUE in the short term, although some of the $\mathrm{N}$ they assimilated should become available to the hazelnuts in later years as the hazelnuts shade them out, which would enhance long-term NUE (Forshey, 1986; Ranells and Wagger, 1996). That such $\mathrm{N}$ recycling may occur in not quantify their impact on NUE. Weeds

this hybrid hazelnut planting system is supported by the results of an $\mathrm{N}$ rate study at the Fillmore site, in which there was a 2-year delay in growth response to applied N (Braun, 2008).

The efficiencies we measured do not include $\mathrm{N}$ retained in belowground tissues at the time of coppicing, which at Amherst could have been significant. They also do not include $\mathrm{N}$ that was removed with nut harvest and leaf drop. We estimated fertilizer $\mathrm{N}$ removed in nuts at Fillmore by multiplying Fillmore nut fNdff, nut $\mathrm{N}$ concentration, and average nut yields. Likewise, we estimated fertilizer $\mathrm{N}$ removed in fall leaf fall by multiplying an estimate of leaf biomass (unpublished data) with the concentration of $\mathrm{N}$ we measured in fallen fall leaves. Estimated NUE, after accounting for this $\mathrm{N}$ removal, but not for $\mathrm{N}$ retained in roots, increased from $5.6 \%$ to $9.0 \%$ for the best treatment at Fillmore. This adjustment did not change the relative efficiencies of the different application dates.

Even when we account for $\mathrm{N}$ removal through nut harvest and leaf fall, the best NUE we estimated is only approximately half that of other woody crops, which average $\approx 20 \% \mathrm{~N}$ recovery (Weinbaum et al., 1992). By comparison, Olsen et al. (2001) recovered $28 \%$ of $\mathrm{N}$ that had been applied at a rate of $120 \mathrm{~g} /$ plant to 11 -year-old European hazelnut trees in Oregon. NUE declines the more N that is applied, especially when $\mathrm{N}$ exceeds plant demand (Weinbaum et al., 1992). This suggests that our $\mathrm{N}$ application rate in this experiment, $6 \mathrm{~g} / \mathrm{plant}$, may have exceeded demand. The 8-year-old hybrid hazelnut bushes at Fillmore contained a total of only $\approx 7 \mathrm{~g} \mathrm{~N} /$ plant in aboveground biomass, whereas the 9- and 13-year-old bushes at Amherst contained 8 and $19 \mathrm{~g} \mathrm{~N} /$ plant, respectively. This suggests a net $\mathrm{N}$ accumulation rate of $\approx 1$ to $3 \mathrm{~g} \mathrm{~N} /$ plant/year for plants in this age range. Based on soil test results from an adjacent $\mathrm{N}$ rate study at the Fillmore site, and assuming a rooting depth of only $30 \mathrm{~cm}$ and a rooting width equal to canopy

Table 2. Dry weight, nitrogen $(\mathrm{N})$ concentration, $\mathrm{N}$ content, and $\mathrm{N}$ uptake efficiency (NUE) of aboveground hybrid hazelnut biomass harvested from Amherst and Fillmore, means (and SEs in parentheses) of all bushes, regardless of treatment.

\begin{tabular}{lcccrr}
\hline Site & $\begin{array}{c}\text { Age of bushes } \\
\text { (years) }\end{array}$ & $\begin{array}{c}\text { Aboveground dry } \\
\text { wt }(\mathrm{kg})\end{array}$ & $\begin{array}{c}\text { Whole-bush N } \\
\text { concn }\left(\mathrm{mg} \cdot \mathrm{g}^{-1}\right)\end{array}$ & $\begin{array}{c}\text { Whole-bush N } \\
\text { content }(\mathrm{G})\end{array}$ & NUE (\%) \\
\hline Amherst & 13 & $2.60(0.22)$ & $7.43(0.17)$ & $18.9(1.5)$ & $5.2(0.5)$ \\
& 9 & $0.93(0.21)$ & $8.07(0.14)$ & $7.5(0.6)$ & $1.9(0.2)$ \\
Fillmore & 8 & $1.16(0.13)$ & $6.09(0.11)$ & $7.1(0.8)$ & $3.4(0.7)$ \\
\hline
\end{tabular}

Table 3. Values and statistics for Figure 3, nitrogen uptake efficiency correlated with aboveground biomass.

\begin{tabular}{lcccr}
\hline N application date & $\mathrm{y}_{0}$ & $\mathrm{a}$ & $\mathrm{Adj} . R_{\text {model }}^{2}$ & $\mathrm{p}_{\text {model }}$ \\
\hline Early April & $-0.01 \mathrm{NS}$ & $2.6 * * *$ & 0.98 & 0.0003 \\
Late April & $-0.03 \mathrm{NS}$ & $1.7 * *$ & 0.73 & 0.0049 \\
Late May & $0.06 \mathrm{NS}$ & $1.3 * *$ & 0.75 & 0.0032 \\
July/August & $1.64 \mathrm{NS}$ & $2.6 \mathrm{NS}$ & 0.30 & 0.0915 \\
September & $2.28 \mathrm{NS}$ & $1.7 \mathrm{NS}$ & 0.03 & $\mathrm{NS}$ \\
\hline
\end{tabular}

All regressions are linear: $\mathrm{y}=\mathrm{y}_{0}+\mathrm{a} \cdot \mathrm{x} *, * *$, and $* * *$ designate coefficient estimates that are significant at $P<0.05,0.01$, and 0.001 , respectively.

NS $=$ Nonsignificant. width, we estimated that at least $3 \mathrm{~g}$ inorganic $\mathrm{N}$ was available to each plant from the soil (Braun, 2008). Thus, soil $\mathrm{N}$ was adequate to supply a demand of 1 to $3 \mathrm{~g} \mathrm{~N} /$ plant/year. In the $\mathrm{N}$ rate study mentioned, which was replicated at four sites, $\mathrm{N}$ responses peaked at $11 \mathrm{~g} \mathrm{~N} /$ plant. These results, together with the results from this tracer study, suggest that the requirements of hybrid hazelnuts for supplemental $\mathrm{N}$ in Minnesota soils are low. They are, in the words of Roversi and Ughini (2005), referring to European hazelnuts, a "frugal" species, given their efficient reuse of endogenous $\mathrm{N}$.

Our data are consistent with research on European hazelnuts (Olsen, 1997; Olsen et al., 2001), which showed that most of the $\mathrm{N}$ for spring leafout was derived from stored $\mathrm{N}$ reserves, not from newly applied fertilizer, and that significant amounts of $\mathrm{N}$ are retained in roots even 1 year after application. Our data also are consistent with the "source-tosink" concept described by Weinbaum et al. (1984): newly absorbed $\mathrm{N}$ is allocated preferentially to the plant part with the greatest demand. Thus, in our experiment, fertilizer $\mathrm{N}$ applied in the spring appeared in leaves relatively quickly, fertilizer $\mathrm{N}$ applied in early August appeared in nuts harvested 1 month later, and fertilizer $\mathrm{N}$ applied in September appeared in new catkins in October. If there was no developing plant part with demand for growth, like in the fall, fertilizer $\mathrm{N}$ was stored in bark. An unexpected result was the extent to which September-applied N remained belowground and appeared in aboveground tissues the next year. This was consistent with results from a preliminary study we conducted (unpublished data), in which $\mathrm{N}$ applied on 11 Oct. appeared in leaves the next year at levels statistically equivalent with $\mathrm{N}$ applied on 1 Sept.

Olsen (2001) reported that the most efficient uptake of soil-applied $\mathrm{N}$ for hazelnuts in Oregon occurs during active spring growth, but our results support a later time for hybrid hazelnuts in Minnesota. If we consider NUE to be the most important parameter, because of the economic and environmental costs of inefficient $\mathrm{N}$ use, then mid- to late summer appears to be the best time to apply $\mathrm{N}$ to hybrid hazelnuts in the Midwest. This is consistent with our hypothesis that NUE would be highest during the period of maximum leaf area, from late May through early August. However, our results are not definitive. Early April, which is consistent with current recommendations, was the most efficient at Amherst and the third most efficient at Fillmore. Late spring through early summer may be more efficient at sites without cool-season weeds. In conclusion, under the conditions of our study, late summer $\mathrm{N}$ applications were the best, although further research is needed to evaluate NUE in the absence of weed pressure and under different weather conditions. Thus, at this time, we cannot recommend one application window over others.

Hybrid hazelnuts exhibited low NUE compared with other woody crops. If over $90 \%$ of applied $\mathrm{N}$ is not absorbed by plants, then 
applying higher $\mathrm{N}$ rates is not the solution to lack of response to N. Instead, growers must strive to improve NUE with an integrated approach. Methods may include improving soil organic matter, applying $\mathrm{N}$ in numerous small doses or in slow-release forms, as recommended by Gray and Garrett (1999), or by fertigation (Alva et al., 2003). Eliminating weeds that may compete for $\mathrm{N}$ should also improve NUE, at least in the short run. Foliar applications could be used to reduce interception of $\mathrm{N}$ by weeds. Olsen (2001) showed that foliar applications are useful as a supplement to soil applications for European hazelnuts in Oregon. For hybrid hazelnuts in Minnesota, which appear to have lower $\mathrm{N}$ requirements, foliar $\mathrm{N}$ applications alone may be adequate.

Most importantly, growers need to more closely match applied $\mathrm{N}$ with plant demand (Sanchez et al., 1995). This is what is recommended in Oregon, where $\mathrm{N}$ application rates are based on age of plant for immature hazelnut plants or on leaf analysis for mature plants (Olsen, 2001). The high correlation we found between aboveground biomass and fertilizer $\mathrm{N}$ uptake supports this recommendation. Approaches to matching applications with demand include applying only as much $\mathrm{N}$ as is removed in the crop and prunings minus estimates of inorganic $\mathrm{N}$ in the soil as proposed by Tagliavini et al. (1996) or applying $\mathrm{N}$ only when leaf $\mathrm{N}$ declines below the threshold of sufficiency as proposed by Worley (1990) for pecans. Based on leaf analyses from our $\mathrm{N}$ rate trials, we propose $2.1 \%$ as the threshold of sufficiency (Braun, 2008).

\section{Conclusions}

Although no single $\mathrm{N}$ application time appeared to be optimum for hybrid hazelnuts, our results support the conclusions from our fertilizer $\mathrm{N}$ rate trials (Braun, 2008), which suggest that the $\mathrm{N}$ demand of hybrid hazelnuts is very low, at least until they start bearing nuts. This probably is the result of their efficient absorption of mineralized $\mathrm{N}$ from the soil and recycling of endogenous N (Millard and Neilsen, 1989). These are traits that help woody crops such as hazelnuts play a valuable role in sustainable agricultural systems.

\section{Literature Cited}

Aguirre, P.B., Y.K. Al-Hinai, T.R. Roper, and A.R. Krueger. 2001. Apple tree rootstock and fertilizer application timing affect nitrogen uptake. HortScience 36:1202-1205.
Alva, A.K., A. Fares, and H. Dou. 2003. Managing citrus to optimize dry mass and nutrient partitioning. J. Plant Nutr. 26:1541-1559.

Baron, L.C. and R. Stebbins. 1981. Growing filberts in Oregon. Oregon Extension Bulletin 628.

Braun, L.C. 2008. Nitrogen fertilization of hybrid hazelnut in the Upper Midwest. PhD Diss., Dept. of Hort. Sci., Univ. Minn, St. Paul, MN.

Dong, S., C.F. Scagel, L. Cheng, L.H. Fuchigami, and P.T. Rygiewicz. 2001. Soil temperature and plant growth stage influence nitrogen uptake and amino acid concentration of apple during early spring growth. Tree Physiol. 21: 541-547.

Forshey, C.G. 1986. An overview of orchard cover crop management. Proc. Annu. Mtg. Wash. State Hort. Assoc. 82:125-128.

Grasmanis, V.O. and D.J.D. Nicholas. 1971. Annual uptake and distribution of $\mathrm{N}^{15}$-labelled ammonia and nitrate in young Jonathan/MM104 apple trees grown in solution cultures. Plant Soil 35:95-112.

Gray, D. and H.E.G. Garrett. 1999. Nitrogen fertilization and aspects of fruit yield in a Missouri black walnut alley cropping practice. Agrofor. Syst. 44:333-344.

Josiah, S.J. 2001. Hybrid hazelnut: An agroforestry opportunity. Univ. of Neb. Lincoln, School of Natural Resource Sci. and Coop. Ext.

Kowalenko, C.G. 1996. Interpretation of autumn soil tests for hazelnut. Can. J. Soil Sci. 76:195202.

Millard, P. 1996. Ecophysiology of the internal cycling of nitrogen for tree growth. J. Plant Nutr. Soil Sci. 159:1-10.

Millard, P. and G.H. Neilsen. 1989. The influence of nitrogen supply on the uptake and remobilization of stored $\mathrm{N}$ for the seasonal growth of apple trees. Ann. Bot. (Lond.) 63:301-309.

Munoz, N., J. Guerri, F. Legaz, and E. PrimoMillo. 1993. Seasonal uptake of ${ }^{15} \mathrm{~N}$-nitrate and distribution of absorbed nitrogen in peach trees. Plant Soil 150:263-269.

Olsen, J. 1997. Nitrogen management in Oregon hazelnut. Acta Hort. 445:263-268.

Olsen, J. 2001. Nutrient management guideHazelnut. Ore. State Univ., Ext. Serv. Bul. EM 8786. 1 Dec. 2008. <http://extension.oregonstate. edu/catalog/pdf/em/em8786-e.pdf $>$.

Olsen, J.L., T.L. Righetti, and E.I. Sanchez. 2001. Absorption and distribution of isotopically labeled nitrogen in the hazelnut tree following ground and foliar applications. Acta Hort. 556:437-444.

Pellett, H.M. and J.V. Carter. 1981. Effect of nutritional factors on cold hardiness of plants. Hort. Rev. (Amer. Soc. Hort. Sci.) 3:144-171.

Ran, Y., R. Habib, B. Bar-Yosef, and A. Erez. 1994. Root volume effects on $\mathrm{N}$ uptake and partitioning in peach trees. Agron. J. 86:530534.

Ranells, N.N. and M.G. Wagger. 1996. Nitrogen release from grass and legume cover crop monocultures and bicultures. Agron. J. 88: 777-782.

Rosecrance, R.C., S.A. Weinbaum, and P.H. Brown. 1996. Assessment of nitrogen, phosphorus, and potassium uptake capacity and root growth in mature alternate-bearing pistachio (Pistacia vera). Tree Physiol. 16:949-956.

Rosen, C.J. and R. Eliason. 2005. Nutrient management for commercial fruit and vegetable crops in Minnesota., Univ. Minn. Extension Serv. BU-05886.

Roversi, A. and V. Ughini. 2005. Further investigations into the mineral uptake of hazelnut orchards. Acta Hort. 686:285-289.

Rutter, P.A. and M.L. Shepard. 2002. Hybrid hazelnut handbook. 1st Ed. Amherst Research Corporation, Canton, MN.

Sanchez, E.E., H. Chimera, D. Sugar, and T.L. Righetti. 1995. Nitrogen management in orchards, p. 327-380. In: Bacon, P.E. (ed.). Nitrogen fertilization in the environment, Marcel Decker, New York, NY.

Tagliavini, M., D. Scudellazi, B. Marangoni, and M. Toselli. 1996. Nitrogen fertilization management of orchards to reconcile productivity and environmental aspects. Fert. Res. 43:93102.

Thevathasan, N.V. and A.M. Gordon. 2004. Ecology of tree intercropping systems in the North temperate region: Experiences from southern Ontario, Canada. Agrofor. Syst. 61: 257-268.

Titus, J.S. and S.M. Kang. 1982. Nitrogen metabolism, translocation, and recycling in apple trees. Hort. Rev. (Amer. Soc. Hort. Sci.) 4: 204-246.

Weinbaum, S.A., R.S. Johnson, and T.M. DeJong. 1992. Causes and consequences of overfertilization in orchards. HortTechnology 2:112-121.

Weinbaum, S.A., I. Klein, F.E. Broadbent, W.C. Micke, and T.T. Muraoka. 1984. Effects of time of nitrogen application and soil texture on the availability of isotopically labeled fertilizer nitrogen to reproductive and vegetative tissue of mature almond trees. J. Amer. Soc. Hort. Sci. 109:339-343.

Weinbaum, S.A., M.L. Merwin, and T.T. Muraoka. 1978. Seasonal variation in nitrate uptake efficiency and distribution of absorbed $\mathrm{N}$ in non-bearing prune trees. J. Amer. Soc. Hort. Sci. 103:516-519.

Weinbaum, S.A. and C. Van Kessel. 1998. Quantitative estimates of uptake and internal cycling of ${ }^{14} \mathrm{~N}$-labeled fertilizer in mature walnut trees. Tree Physiol. 18:795-801.

Worley, R.E. 1990. Long-term performance of pecan trees when nitrogen application is based on prescribed threshold concentrations in leaf tissue. J. Amer. Soc. Hort. Sci. 115:745-749.

Youssefi, F., S.A. Weinbaum, and P.H. Brown. 2000. Regulation of nitrogen partitioning in field-grown almond trees: Effects of fruit load and foliar nitrogen applications. Plant Soil 227: 273-281. 